\title{
English Class Design to Improve Students’ Oral Fluency*
}

\author{
JIA Xiao-yun \\ University of Shanghai for Science and Technology, Shanghai, China
}

\begin{abstract}
The paper discusses the concept of oral fluency and some factors which influence students' oral fluency, analyses the data from first-year English majors in USST and also helps design some effective ways to provide every chance to "force" students to speak English. Finally, the paper points out that oral class is absolutely not the only class to practice speaking English, other classes such as Comprehensive English, Extensive English, etc., can also be used to improve the students' oral fluency effectively if designed properly.
\end{abstract}

Keywords: L2 fluency, all-around environment, interaction

\section{Introduction}

With the globalization, English, of course, should play an important role in cross-cultural communication. People, with a good command of English speaking ability will be urgently demanded in different fields. Therefore, how to improve students' English oral fluency in communication so as to make them more adaptable to society has always been a major concern for language teachers. Histrorically, teaching English usually focuses on reading and writing, but little attention has been paid to oral English. The result is that in Chinese universities, most students spend lots of time in finishing their tasks in reading and writing but little time in practicing their oral English. Besides, class hours for oral is far from enough. In that case, controversy as to the optimal ways of learning and teaching oral English arises. The paper tries to find the better and effective ways to solve the problem, showing that oral class is not the only class to teach students' oral English, but other classes such as Comprehensive English, Extensive English, etc., if designed properly, can also be used to effectively improve the students' oral fluency.

\section{The Updated Definition of L2 Oral Fluency}

Oral fluency, according to Fillmore (1979), is divided into four types that reflect different abilities of a speaker: the ability to talk without frequent and lengthy pauses and monitor his speech unconsciously and automatically; the ability to talk in coherent, reasoned, and "semantically dense" sentences; the ability to express himself without getting tongue-tied when an unexpected situation happens; the ability to use the language freely and creatively. In his opinion, a thorough consideration should be given to fluency, correctness, flexibility, and creativity. Brumfit (1984) views L2 fluency as "the maximally effective operation of the language system so far acquired by the student" (p. 42); Sajavaara (1987) maintains linguistic acceptability and smooth continuity of

\footnotetext{
* Acknowledgements: This paper is sponsored by both Shanghai Core Courses Project for 2015 (1K-16-305-001) and University of Shanghai for Science and Technology Top-Quality Courses Cultivation Project for 2016 (10-16-113-002).

JIA Xiao-yun, associate professor, M.A., College of Foreign Language, University of Shanghai for Science and Technology.
} 
speech are the two aspects combined in L2 fluency; Schmidt (1992) prefers to call fluency an "automatic procedural skill"; Skehan (1996) emphasizes that fluency cannot be independent of meaning because it reflects the learner's ability in dealing with real time communication. Riazantseva (2001) suggests that fluency is also related to controlling pausing and hesitation phenomena. According to her findings, L2 learners can achieve oral fluency by knowing how to pause and hesitate. Derwing, Munro, and Wiebe (1998) hold that oral fluency is an important characteristic of L2 speech, which is often the object of evaluation in testing L2 skills.

To conclude, many researchers have defined fluency from different perspectives and proposed some aspects that fluency concerns, from which, some common features of oral fluency may be summarized as following: continuity and acceptability. According to ZHANG Wen-zhong (2002), he holds that oral fluency should be operationally defined as the ability to speak with continuity, acceptability, and the ability to produce coherent utterances and stretches of speech.

\section{The Factors Influencing Oral Fluency}

The above researchers have attempted to define fluency from different perspectives and have stated many aspects in the concept, which lead to different opinions of factors influencing oral fluency. Semantic, articulate, and lexical-syntactic elements are undoubtedly very important factors to influence oral fluency. Empirically, Huang and Van Naerssen (1987) found that reading practice stands out as the most significant predictor of oral proficiency for Chinese English learners. They suggest that memorizing chunks of language, phrases, or prefabricated routines may help to get conversations going and to build up confidence in speaking. Sajavaara (1987) who maintains that during communication and interaction, L1 oral fluency always influences L2 fluency, and familiarity with the situation may all affect speaking fluency.

\section{Current Situation and Problems of OE Practicing of First-Year English Majors}

The following table clearly shows the current situation of oral practicing in English class. There are altogether 49 students, majoring in English for International Business.

Table 1

The Current Situation of OE Practicing

\begin{tabular}{lllll}
\hline Classes & Periods/week & Main contents & $\begin{array}{l}\text { Students' speaking } \\
\text { time (min) }\end{array}$ & Volunteer \\
\hline $\begin{array}{l}\text { Comprehensive } \\
\text { English }\end{array}$ & 4 & $\begin{array}{l}\text { Report (1 person 10 min.) Explanation of } \\
\text { vocabulary \& texts (including Q\&A) } \\
\text { Checking exercises }\end{array}$ & $>10$ & $\begin{array}{l}\text { 1-2 giving active } \\
\text { responses to } \\
\text { teachers' questions } \\
\text { Extensive English }\end{array}$ \\
2 & 2 & $\begin{array}{l}\text { fast reading } \\
\text { Listening to Step by Step, and songs } \\
\text { occasionally }\end{array}$ & 5 & Few \\
$\begin{array}{l}\text { English listening } \\
\begin{array}{l}\text { Oral English } \\
\text { (Foreign teacher) }\end{array}\end{array}$ & 2 & Topic discussion, role play & 25 & $4-5$ \\
\hline
\end{tabular}

Out of class: Few of them have their talks in English, only for fun.

Notes. School: University of Shanghai for Science and Technology; Class: International Business. Numbers of Students: 49.

From the Table 1 above, we can see that students have insufficient time to talk in different classes. The Comprehensive English class only serves as teacher-centered class, in which teachers explain everything, leaving almost no time for the students to talk. As for Extensive English class, students pay less attention to oral practice, compared with comprehensive English class. Teachers' task is explaining new words and phrases, checking 
answers, and arranging time for fast readings, so there is little interaction between the students and the teacher. In listening and oral class, students do "open their mouths", but since the teacher usually acts as a guide and leaves most time for students to talk, most students either speak Chinese or discuss something which has nothing to do with the class. In such cases, students will definitely lack their desire to practice speaking English both in and after class.

\section{Class Design to Improve Oral Fluency in English Teaching}

Since the focus of language teaching aims at maximizing students' language use, the teacher should not only create a pleasant and harmonious atmosphere, but also produce as many chances as possible to "force" students to open their mouths. In fact, each type of English class can be designed to practice speaking English. Given enough time, the students' oral fluency will definitely be improved.

\section{Comprehensive English Class Design}

At the beginning of each comprehensive English class, the teacher puts many topics prepared in advance in a box, and lets a student choose one at random from the box, and then each student gives a spontaneous presentation. It is certain that students may feel nervous and do not speak as fluently as what they prepared beforehand or may even go blank. But only under such "press" can they really learn to speak rather than to recite. The topics should be close to life so that students could have a lot to say and to avoid silence to maximal extent. For example, the teacher can ask the student to talk about women in this society such as concepts towards life, marriage, clothing, and beauty or stories about film stars, eating, traveling, love, TV programs, etc. Since these are all that students are familiar with, they will definitely arouse students' great interests and ease the speaker's anxieties. In the beginning, the whole class may not be accustomed to this tough task, but soon they will gradually adapt themselves to such class pattern, and their oral English will make a difference as time goes by.

\section{Extensive English Class Design}

The main objective of extensive class is to train students' reading ability. We can just start from reading. To begin with, students are asked to read an article either from textbooks or outside for about ten minutes. Then students can make some comments on what they read. Finally, it is quite feasible to spend 20 minutes discussing or just doing Q\&A as a finishing part of a unit. Teachers can decide on whether to use the topics and questions in the book or not and make sure to provide everyone with same chance. On the one hand, the students can fully understand the meaning of what they are asked to read, on the other hand, they can open their mouths to express themselves, which is more important for them to practice speaking English.

\section{English Listening Class Design}

Listening class is a good channel for both practicing listening and speaking as well. In our usual practices, teachers play the tape, while students do the exercises, and then the teacher checks the answer. Such class is obviously more mechanic and tedious, without stimulating the students' motives to "open their mouth". But if the teaching method is changed slightly, things will be different. For example, while listening, students are not allowed to do the exercises but required to retell what they heard about. Such training will improve not only listening and speaking abilities, but also memorizing and expressing abilities as well, and then they can finish the task for each exercise, which is much easier for they have already got the idea of the material. 


\section{Oral English Class Design}

The above mainly discussed some effective ways used for students to practice speaking English in non-oral English classes. However, if students want to reach the goal of oral fluency, they must make full use of oral class. Here, the 4/3/2 technique, put forward by Maurice (1983) can be introduced into the class. That is, learners deliver a four-minute talk on his familiar topic to a partner. Then they change partners and give the same talk to a different partner but within three minutes. And finally they change partners again and deliver the same talk in two-minute time limit. Thus, each speaker has to practice the same talk three times to three different listeners with a decrease in time. Each of these three features, a changing audience, repetition and decreasing time amount for delivery, makes an important contribution to the development of oral fluency. For example, we could let students act as sales representatives. He/she is required to successfully sell a product (maybe mobile phone) to three different persons (boy, girl, elder). In such case, the speaking techniques must be changed with different objects and time. Boys usually pay attention to the convenience, high quality, or business functions of a mobile; while girls probably attach much importance to its outlook, pleasant sounds, and various games; and elders value the practical functions in most cases. The speaker should be aware of these differences and develop its features accordingly in front of three objects. And when given four minutes, the advantages and functions of the mobile shall be presented in a detailed way, when time is limited two minutes, he shall grasp the main points and try to express himself as logically as possible. After experiencing the $4 / 3 / 2$ practicing, there is no doubt that the student will speak more fluently and in a more confident way.

Oral class could be very interesting and attractive to students if designed elaborately. Think and create some oral games. If students are willing to speak English and take part in activities actively, the class proves to be successful. The following are some activities which have been proved successfully in English teaching.

Activity 1. Divide the class into two groups: A and B. Group A can ask Group B 10 questions to guess what B prepares and Group B just answers "yes/no" to A's questions. For instance, B bears "one image" in mind. Members in Group A ask: Is it animated? B answer: No. Do we place it at home? B answers: Yes. Is it for our daily life? B answers: Yes... After 10 questions, A shall give out the answer. And then change the role, B for guessing and A for answering (one round/period is suitable).

Activity 2. Another guessing game, but only one student prepares the object and he shall give four hints and let the others guess. For example, one student says: "disease, insect, water and summer", then the other student gives the word "mosquito", for mosquito possesses the above four characteristics. Such activities will not take too much time but involve most students to participate in, which yields twice the result with half the effort.

Activity 3. Students listen to a story but the teacher shall stop it halfway. Then all the students are asked to stand up to continue the story one by one. Everyone gives two utterances and then he/she could sit down. In the end, the last student is to give a logical ending to the story. This activity is relatively demanding. Understanding the listening material is the basic step. They are required to be highly concentrated on and likely to get nervous, as they do not know what others will say and how to continue. This game will not only greatly train students' quick responses and psychological conditions, but also improve their oral fluency ability.

\section{Conclusion}

Teaching English can be very interesting. Successful teaching involves an increased awareness of what the 
teacher should do now and how to make a little change from the traditional way of teaching. Different English class design mentioned above aims to offer a brand new method of all-around oral training. These game-like activities will be popular as they are fresh for students and feasible for teachers. It does not need special facility but has the following advantages: (1) Students have much more opportunities to speak in any kinds of English classes; (2) feedback between student-student and teacher-student increases greatly; and (3) harmonious and relaxed class will definitely motivates students involvement. All these provide guarantees for improving oral fluency.

\section{References}

Brumfit, C. (1984). Communicative methodology in language teaching. Cambridge: Cambridge University Press.

Derwing, T. M., Munro, M. J., \& Wiebe, G. (1998). Evidence in favor of a broad framework for pronunciation instruction. Language Learning, 48(3), 393-410.

Fillmore, C. J. (1979). On fluency: Perspectives on fluency (pp. 43-60). Ann Arbor: University of Michigan Press.

Huang, X. H., \& Van Naerssen, M. (1987). Learning strategies for oral communication. Applied Linguistics, 8(3), 287-307.

Maurice, K. (1983). The fluency workshop. TESOL Newsletter, 17(4), 29.

O’Malley, J. M., \& Chamot, A. U. (1990). Learning strategies in second language acquisition. Cambridge, England: Cambridge University.

Riazantseva, A. (2001). Second language proficiency and pausing: A study of Russian speakers of English. Studies on Second Language Acquisition, 23, 497-526.

Sajavaara, K. (1987). Second language speech production: Factors affecting fluency. In H. Dechert and M. Raupach (Eds.), Psycholinguistic models of production (pp. 45-65). Norwood, NJ: Ablex Publishing Corporation.

Schmidt, R. (1992). Psychological mechanisms underlying second language fluency. Studies in Second Language Acquisition, $14(3), 57-85$.

Scrivener, J. (2002). Learning teaching: A guide book for English language teachers. Shanghai Foreign Language Education Press.

Skehan, P., \& Foster, P. (1997). Task type and task processing conditions as influences, on foreign language performance. Language Teaching Research, 1(3), 185-212.

Tam, M. K. (1997). Building fluency: A course for non-native speaker of English. English Teaching Forum, 35(1), 26. Retrieved from http://eca.state.gov/forum/vols/vol35/no1/p26.htm

ZHANG, W. Z. (2002). The development of L2 oral fluency in the EFL classroom setting. Changsha: Hunan Educational Press. 